\title{
Correction: Satisfaction of scientists during the COVID-19 pandemic lockdown
}

\author{
Isabel J. Raabe (1), Alexander Ehlert (1), David Johann \& Heiko Rauhut
}

Correction to: Humanities and Social Sciences Communications https://doi.org/10.1057/s41599-020-00618-4, published online 4 November 2020.

Table 2 in the original paper has been corrected to ensure that the columns in the top section are aligned appropriately with those in the lower section.

In addition, the following sentence in the legend to Fig. 1 has been corrected as follows to improve clarity:

Original: For illustration purposes, this distribution was rescaled to rescaled to cover only a fraction of the figure.

Changed to: For illustration purposes, this distribution was rescaled to cover only a fraction of the figure.

Published online: 04 December 2020

\footnotetext{
(c) (i) Open Access This article is licensed under a Creative Commons Attribution 4.0 International License, which permits use, sharing, adaptation, distribution and reproduction in any medium or format, as long as you give appropriate credit to the original author(s) and the source, provide a link to the Creative Commons license, and indicate if changes were made. The images or other third party material in this article are included in the article's Creative Commons license, unless indicated otherwise in a credit line to the material. If material is not included in the article's Creative Commons license and your intended use is not permitted by statutory regulation or exceeds the permitted use, you will need to obtain permission directly from the copyright holder. To view a copy of this license, visit http://creativecommons.org/licenses/by/4.0/.
}

(C) The Author(s) 2020 